\title{
Quantifying environmental stress-induced emissions of algal isoprene and monoterpenes using laboratory measurements
}

\author{
N. Meskhidze ${ }^{1}$, A. Sabolis ${ }^{1, *}$, R. Reed ${ }^{2}$, and D. Kamykowski ${ }^{1}$ \\ ${ }^{1}$ Marine, Earth, and Atmospheric Science, North Carolina State University, Raleigh, NC, USA \\ ${ }^{2}$ Center for Applied Aquatic Ecology, North Carolina State University, Raleigh, NC 27606, USA \\ *now at: Scott Safety, Monroe, NC 28110, USA
}

Correspondence to: N. Meskhidze (nmeskhidze@ncsu.edu)

Received: 19 August 2014 - Published in Biogeosciences Discuss.: 19 September 2014

Revised: 10 December 2014 - Accepted: 26 December 2014 - Published: 2 February 2015

\begin{abstract}
We report here production rates of isoprene and monoterpene compounds ( $\alpha$-pinene, $\beta$-pinene, camphene and d-limonene) from six phytoplankton monocultures as a function of irradiance and temperature. Irradiance experiments were carried out for diatom strains (Thalassiosira weissflogii and Thalassiosira pseudonana), prymnesiophyte strains (Pleurochrysis carterae), dinoflagellate strains (Karenia brevis and Prorocentrum minimum), and cryptophyte strains (Rhodomonas salina), while temperature experiments were carried out for diatom strains (Thalassiosira weissflogii and Thalassiosira pseudonana). Phytoplankton species, incubated in a climate-controlled room, were subject to variable light (90 to $900 \mu \mathrm{mol} \mathrm{m}{ }^{-2} \mathrm{~s}^{-1}$ ) and temperature (18 to $30^{\circ} \mathrm{C}$ ) regimes. Compared to isoprene, monoterpene emissions were an order of magnitude lower at all light and temperature levels. Emission rates are normalized by cell count and Chlorophyll $a$ (Chl $a$ ) content. Diatom strains were the largest emitters, with $\sim 2 \times 10^{-17} \mathrm{~g}(\mathrm{cell})^{-1} \mathrm{~h}^{-1}(\sim 35 \mu \mathrm{g}$ $(\mathrm{g} \mathrm{Chl} a)^{-1} \mathrm{~h}^{-1}$ ) for isoprene and $\sim 5 \times 10^{-19} \mathrm{~g}(\text { cell })^{-1} \mathrm{~h}^{-1}$ $\left.\left(\sim 1 \mu \mathrm{g}(\mathrm{g} \mathrm{Chl} a)^{-1}\right) \mathrm{h}^{-1}\right)$ for $\alpha$-pinene. The contribution to the total monoterpene production was $\sim 70 \%$ from $\alpha$-pinene, $\sim 20 \%$ for d-limonene, and $<10 \%$ for camphene and $\beta$ pinene. Phytoplankton species showed a rapid increase in production rates at low irradiance $\left(<150 \mu \mathrm{mol} \mathrm{m}^{-2} \mathrm{~s}^{-1}\right)$ and a gradual increase at high $\left(>250 \mu \mathrm{mol} \mathrm{m}^{-2} \mathrm{~s}^{-1}\right)$ irradiance. Measurements revealed different patterns for time-averaged emissions rates over two successive days. On the first day, most of the species showed a distinct increase in production rates within the first $4 \mathrm{~h}$ while, on the second day, the emission rates were overall higher, but less variable. The data suggest that enhanced amounts of isoprene and monoterpenes
\end{abstract}

are emitted from phytoplankton as a result of perturbations in environmental conditions that cause imbalance in chloroplasts and force primary producers to acclimate physiologically. This relationship could be a valuable tool for development of dynamic ecosystem modeling approaches for global marine isoprene and monoterpene emissions based on phytoplankton physiological responses to a changing environment.

\section{Introduction}

The age of global warming has brought about a heightened amount of attention to the interactions between life and the Earth's climate. Global climate models with advanced treatment of manmade aerosols and pollutants and their interactions with clouds have been widely used for calculations from climate sensitivity to greenhouse gas emissions. Over the last decade, a large number of studies have been devoted to reducing the uncertainty in anthropogenic aerosol radiative forcing of climate. However, a lesser-known uncertainty in climate predictions as a result of natural aerosols has only recently been explored (Meskhidze et al., 2011; Carslaw et al., 2013). As estimates of anthropogenic forcing are based on a pre-industrial atmosphere composed mainly of natural aerosols, the representation of natural aerosols in climate models strongly influences the predictions of current and future climate effects of anthropogenic aerosols (Hoose et al., 2009). Data analysis shows that up to $45 \%$ of the variance of aerosol forcing arises from uncertainties in natural emissions of volcanic sulfur dioxide, marine dimethyl sulfide, biogenic volatile organic carbon (BVOC), biomass burning, and sea 
spray (Carslaw et al., 2013). Moreover, recent studies have revealed that several biotic and abiotic stresses associated with changing environmental factors increase the emission of BVOC from both terrestrial and aquatic plants (Rinnan et al., 2014). Therefore, the Earth's climate models should be able not only to characterize aerosol and trace gas emissions from the Earth's various ecospheres and quantify the uncertainties associated with these emissions, but also to predict the changes in the emission rates that are related to the human activity.

While climate is regulated by numerous factors, some of the largest effects of natural aerosols on climate radiative forcing occur over the oceans, where boundary layer clouds cover the vast expanse of the Earth's surface and have some of the highest sensitivity of cloud albedo to cloud condensation nuclei concentrations (Platnick and Twomey, 1994; Hoose et al., 2009). Thus, factors that regulate the concentration of aerosols over the oceans and the resulting reflectivity of low-level marine clouds can critically affect the climate system as a whole (e.g., Randall et al., 1984; Stevens et al., 2005). The existence of physical relationships between marine biota, gas emissions, aerosols, clouds, and radiative forcing has been hypothesized for more than several decades (Shaw, 1983). If such a relationship exists, the observed tight coupling between environmental change and plankton dynamics (such as community structure, timing of seasonal abundance, and geographical range) (Hays et al., 2005) may have a considerable impact on the current and future climates.

Marine aerosols associated with ocean biota can be derived from both primary (through bubble bursting) and secondary (through oxidation of phytoplankton-emitted trace gases) processes (Blanchard, 1964; Hoffman and Duce, 1976; Charlson et al., 1987; O’Dowd et al., 2004; Meskhidze and Nenes, 2006; O'Dowd and Leeuw, 2007). Recent reviews summarized the state of the art and remaining uncertainties in production mechanisms, number concentration, size distribution, chemical composition, and optical properties of sea spray aerosols (de Leeuw et al., 2011; Meskhidze et al., 2013). In addition to primary aerosols, many oceanic trace gases produced as a consequence of marine biological activity have also been shown to have global-scale impacts on biogeochemical cycling, tropospheric and stratospheric ozone depletion, photochemical processing, and secondary aerosol formation (Carpenter et al., 2012, and references therein). Although the global BVOC emission rate of phytoplankton is considerably small compared to terrestrial vegetation, the emissions occur over relatively pristine regions and therefore have the ability to influence oxidation capacity and natural aerosol formation in remote marine and coastal regions (Luo and Yu, 2010).

Following an initial finding for a marine source of isoprene (Bonsang et al., 1992; Broadgate et al., 1997) and monoterpenes (Yassaa et al., 2008), an increasing number of studies have focused recently on improved understanding of their potential effects on coastal air quality (Palmer and Shaw, 2005; Liakakou et al., 2007; Gantt et al., 2010a, b) and climate (Gantt et al., 2009; Roelofs, 2008; Meskhidze et al., 2011). Isoprene production rates have been determined for microalgae (Moore et al., 1994; Milne et al., 1995; Mckay et al., 1996; Shaw et al., 2003; Gantt et al., 2009; Bonsang et al., 2010; Exton et al., 2013), macroalgae (Broadgate et al., 2004), and microbial communities (Acuña Alvarez et al., 2009). Despite this, large discrepancies remain in bottom-up and top-down estimates of marine sources of isoprene, having a wide range from $\sim 0.1$ to $1.9 \mathrm{Tg} \mathrm{Cyr}^{-1}$ and $\sim 11.6 \mathrm{Tg} \mathrm{C} \mathrm{yr}^{-1}$, respectively (Milne et al., 1995; Palmer and Shaw, 2005; Gantt et al., 2009; Lou and Yu, 2010). An even greater level of uncertainty exists for sources of ocean-derived monoterpenes that were proposed to range from 0.013 to $29.5 \mathrm{Tg} \mathrm{C} \mathrm{yr}^{-1}$ (Luo and $\mathrm{Yu}, 2010)$. Past studies also revealed that isoprene emissions from phytoplankton are strongly correlated with incoming radiation (Shaw et al., 2003; Gantt et al., 2009). Both studies showed a rapid increase in isoprene production at low irradiance levels $\left(<150 \mu \mathrm{mol} \mathrm{m}^{-2} \mathrm{~s}^{-1}\right)$ and a gradual increase at higher irradiance levels $\left(>250 \mu \mathrm{mol} \mathrm{m}^{-2} \mathrm{~s}^{-1}\right)$. Emission rates of monoterpenes from nine algal species have also been reported, but only at significantly lower (30 to $100 \mu \mathrm{mol} \mathrm{m}^{-2} \mathrm{~s}^{-1}$ ) irradiance levels (Yassaa et al., 2008). When studying emission of isoprene and monoterpenes from different algal species, most of the research has been focused on either long-term emission rates from normal growth conditions or short-term emissions as responses to different environmental stress factors (i.e., light and thermal stress). Little attention has been devoted to production of isoprene and monoterpenes from phytoplankton as a function of time when they are forced to adjust or acclimate physiologically.

During their lifetime, phytoplankton can also be exposed to temperature values considerably different from the ones at which cultures have been acclimated due to vertical mixing in the water column. Eppley (1972) pioneered the study of phytoplankton growth rates at acclimated temperature. Schofield et al. (1998) investigated temperature effects on dinoflagellate photosynthetic light and dark reactions, while Staehr and Birkeland (2006) discussed temperature effects on broader aspects of phytoplankton biochemistry and metabolism. Production of isoprene and monoterpenes from marine algae as a result of simultaneous changes in temperature and light regimes has not been previously investigated.

This study explores isoprene and monoterpene production rates that arise in response to variations in environmental factors for light-stressed and temperature-stressed regimes from variable phytoplankton species. Four broadly distributed and globally common phytoplankton classes (Cermeño et al., 2010) and more than one species of diatom and dinoflagellate were used to generalize the class coverage beyond just diatoms and dinoflagellates and only one species per class. The six algal species were selected based on a variety of 
factors including use in previous photosynthetic and physiological studies, production of secondary metabolites and toxins, rapid growth rate and high nutritional value. The term "stress" is debatable in the ecological sense; here, it denotes an external constraint limiting the rates of resource acquisition, growth or reproduction by marine algae (Grime, 1989). The $12 \mathrm{~h}$ light/temperature cycles, different from those at which the bulk cultures were incubated in the climate control room, were used to observe a possible stress-related response of BVOC production. The $12 \mathrm{~h}$ dark cycle at the standard temperature in the climate-controlled room was intended to give phytoplankton some time to repair the photo/temperature damage that they may have sustained. Although full acclimation to a severely altered environment may require more than $12 \mathrm{~h}$ to reach a new equilibrium, timescales (hours to days) were selected to explore BVOC production rates that could be a response of phytoplankton to variable light/temperature conditions potentially occurring as a result of turbulent motions in the surface mixed layer (e.g., Cullen and Lewis, 1988; Geider et al., 1996). The experimental irradiance conditions applied here are within the global range of natural environmental conditions. Boreal/austral summer noon surface photosynthetically active radiation (PAR) approaches $2000 \mu \mathrm{mol} \mathrm{m}^{-2} \mathrm{~s}^{-1}$ seasonally and regularly from $40^{\circ} \mathrm{N}$ to $40^{\circ} \mathrm{S}$, and can do so between $60^{\circ} \mathrm{N}$ and $60^{\circ} \mathrm{S}$ (Bouvet et al., 2002). Therefore, the challenges of abrupt irradiance intensity increases used here are conceivable in the upper ocean due to displacement in the vertical light gradient; however, the challenges of abrupt temperature changes become less likely at the extremes of the applied range. For temperature, these experiments represent the natural condition under a limited temperature range ( $\pm 4{ }^{\circ} \mathrm{C}$ around acclimation temperature), but become a test of physiological capability over a larger temperature range. The temperature values were based on the previous works documented in Eppley (1972), Schofield et al. (1998) and Staehr and Birkeland (2006).

\section{Instrumentation and method development}

\subsection{Incubation and sampling methodology}

Figure 1 shows a schematic diagram for the incubation and sampling methodology. Phytoplankton monocultures were grown in a climate control room with a constant temperature of $22^{\circ} \mathrm{C}$ and a $12 \mathrm{~h}$ on $/ 12 \mathrm{~h}$ off light cycle at $90 \mu \mathrm{mol} \mathrm{m}{ }^{-2} \mathrm{~s}^{-1}$ and $0 \mu \mathrm{mol} \mathrm{m}{ }^{-2} \mathrm{~s}^{-1}$, respectively. In order to ensure similar growth conditions for each monoculture, larger bulk samples were grown for each batch of the cultures; then, smaller volumes were extracted and used for the analysis. The following species were grown in 9 L Pyrex bottles for analysis: diatom strains - Thalassiosira weissflogii (T. weiss.) (CCMP 1336) and Thalassiosira pseudonana (T. pseud.) (CCMP 1335); prymnesiophyte strains - Pleurochrysis carterae (P.

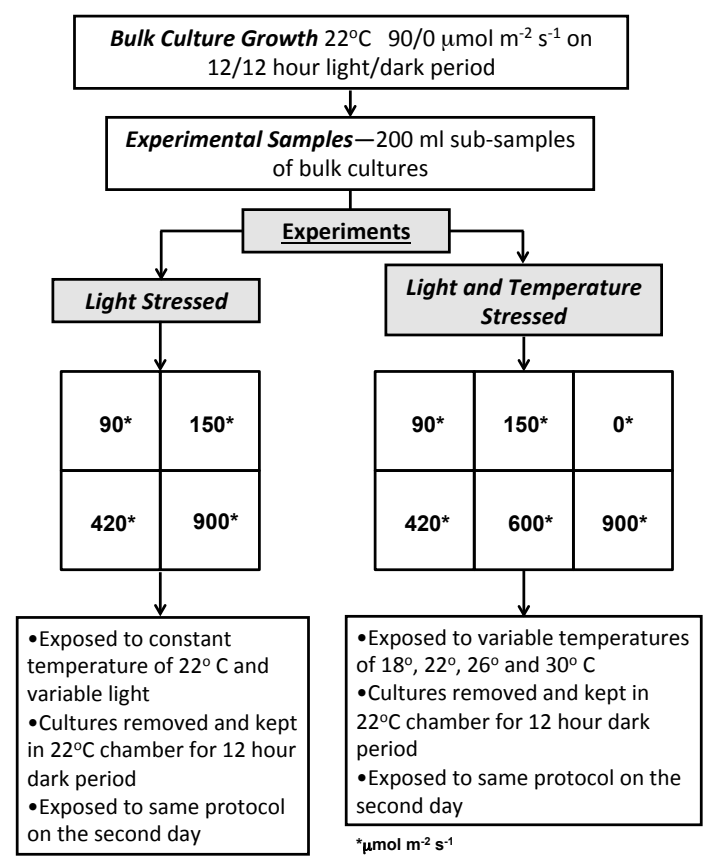

Figure 1. Schematic diagram of the experimental setup.

carter.) (CCMP 645); dinoflagellate strains - Karenia brevis (K. brevis) (CCMP 718, CCMP 2229) and Prorocentrum minimum (P. minim.) (CCMP 1329); and cryptophyte strains - Rhodomonas salina (R. salina) (UTEX 2423). Larger bulk samples were prepared in autoclaved filtered seawater and with an L1-based medium (Sigma-Aldrich, St. Louis, MO). Samples were then sealed at the top with aluminum foil, to allow for air transfer to the culture, and incubated in the climate control room. Bulk samples were incubated in the climate control room for 2 weeks for the diatoms, cryptophyte, and prymnesiophyte species and 3 weeks for the slower growing dinoflagellate species. These were the approximate time frames in which each monoculture was able to reach a maximum/stable biomass, where growth rate was light-limited due to self-shading. Monocultures were not axenic, but multiple steps such as acid washing all glassware and autoclaving seawater and nutrients were used to reduce the likelihood of bacterial contamination within the cultures.

Smaller samples $(200 \mathrm{~mL})$ of each monoculture were extracted from the bulk containers and transferred to $250 \mathrm{~mL}$ borosilicate glass flasks for analysis purposes, leaving $50 \mathrm{~mL}$ of gas headspace in each purging vessel. The smaller volume monocultures were then subjected to different light and temperature regimes. These different regimes were used to assess differences between normal BVOC emissions and the emissions due to physiological stress-induced effects. An apparatus used for assessing the effect of changing incoming solar radiation for BVOC production of phytoplankton was composed of a tank suspended over six halogen lights (Philips $250 \mathrm{~W}$ projector lamp no. 13095) and a circulating water bath 
used to control the temperature within the tank. To vary the light intensities within the tank, the bottom of the water bath was lined with several different layers of semi-translucent fiberglass screens that attenuate a portion of the light reaching the samples. Irradiance inside the water bath was then measured by a QSL-100 laboratory quantum scalar irradiance meter (Biospherical Instruments, San Diego, CA). A Neslab CFT-33 refrigerated recirculator (Thermo Fisher Scientific, Waltham, MA) was used to control the water temperature. Emission analysis experiments were carried out to examine the effects of light and temperature stress on different phytoplankton species.

For the light-dependent production experiments, four different irradiance intensities were used: 90, 150, 420 and $900 \mu \mathrm{mol} \mathrm{m} \mathrm{m}^{-2} \mathrm{~s}^{-1}$. At the end of the $12 \mathrm{~h}$ dark cycle, the bulk cultures from the climate-controlled room were transferred to four $250 \mathrm{~mL}$ purging vessels placed in the circulating water bath kept at $22^{\circ} \mathrm{C}$ (the same as the climate-controlled room). The samples were initially purged (in the dark) to remove the excess BVOC that may have been generated during their growth in the climate-controlled room. At time zero, the lights were turned on and the individual samples were subjected to one of the respective irradiance intensities defined above. During the $12 \mathrm{~h}$ incubation time, samples were purged and analyzed every $\sim 2 \mathrm{~h}$ over $12 \mathrm{~h}$, leading to a total of six measurements for each sample. Since cultures were originally incubated at $12 \mathrm{~h}$ of dark and $12 \mathrm{~h}$ of light conditions, BVOC emission rates measured at irradiances higher than $90 \mu \mathrm{mol} \mathrm{m}^{-2} \mathrm{~s}^{-1}$ are defined as the light-stress-induced production. After the $12 \mathrm{~h}$ lights-on cycle, the phytoplankton samples were returned back to the climate-controlled room, where they were subjected to a $12 \mathrm{~h}$ dark cycle. After this dark cycle, species were placed in the circulating water (at $22^{\circ} \mathrm{C}$ ) bath again and the same sampling procedure was repeated.

For temperature- and light-dependent production experiments, four different water temperatures $(18,22,26$ and $\left.30^{\circ} \mathrm{C}\right)$ and six different irradiance intensities $(0,90,150$, 420, 600 and $900 \mu \mathrm{mol} \mathrm{m}^{-2} \mathrm{~s}^{-1}$ ) were used. The sampling methodology was similar to the light-dependent production experiments described above. However, due to the large number of experiments, only two diatom strains ( $T$. weiss. and $T$. pseud.) were used for the analysis. The sampling frequency was also reduced to one purging at the end of the $12 \mathrm{~h} \mathrm{cy-}$ cle to obtain a broader range of data for variable temperature and light regimes. At the end of a $12 \mathrm{~h}$ cycle, the bulk cultures were transferred to a climate control room and kept in a full $12 \mathrm{~h}$ dark cycle at $22^{\circ} \mathrm{C}$, after which the same sampling procedure was repeated. Since cultures were originally incubated to an irradiance intensity of 0 and $90 \mu \mathrm{molm}^{-2} \mathrm{~s}^{-1}$ (on a $12 \mathrm{~h}$ cycle) at $22^{\circ} \mathrm{C}$, the BVOC emission rates measured for such a sampling setup were defined as the lightstressed/temperature-stressed production.

\subsection{BVOC analysis}

The experimental system consisted of a Varian 450-GC gas chromatograph (GC) attached to a 220-MS ion trap mass spectrometer (MS). The GC column was a $25 \mathrm{~m} \times 0.32 \mathrm{~mm}$ I.D. CP-PoraBOND PLOT Q fused silica column (Varian, Inc.). Ultra high purity (UHP) helium was used as a carrier gas for the system. Data collection and analysis were performed with Varian MS Workstation (version 6.X) software equipped with the National Institute of Standards and Technology (NIST) library for chemical compound identification. A pre-concentrating system consisted of a purge and trap CDS 8000 sample concentrator unit (CDS Analytical, PA) equipped with a Vocarb 3000 (K Trap) attached in-line with the GC/MS system.

The following sampling procedure was used for all emission analyses. The purging vessel (a $250 \mathrm{~mL}$ borosilicate glass Erlenmeyer flask) was sealed at the top with a silicone stopper and borosilicate glass tubing was used as inlet and outlet ports. To avoid VOC contamination (e.g., emissions from plastics or rubber) in connection lines, purging vessels, or port connections, only borosilicate glass or 316 stainless steel or high purity silicone tubing (McMaster-Carr Inc., Atlanta, GA) was used. The inlet was attached to a mixture of $350 \mathrm{ppm} \mathrm{CO}$ balanced with $78 \%$ nitrogen and $21 \%$ oxygen. This gas mixture (a "blanket gas") was bubbled through the liquid sample to liberate BVOC in the water into the headspace of the flask. The blanket gas was used for purging, as the lab air may have been contaminated by VOCs. The $\mathrm{CO}_{2}$ level in the blanket gas was equivalent to that of current atmospheric levels. The gas stream was then passed into the wet trap of the CDS concentrator (set to $200^{\circ} \mathrm{C}$ ), followed by the sorbent trap (set to $40^{\circ} \mathrm{C}$ ), where the BVOCs in the gas stream are trapped. After $35 \mathrm{~min}$ of purging, the sample vessel at a flow rate of $0.40 \mathrm{slpm}$, a solenoid valve in the CDS concentrator was switched to inline the sorbent trap with the GC/MS through a transfer line. The trap was desorbed for $5 \mathrm{~min}$ at $250^{\circ} \mathrm{C}$ and transferred to the GC inlet (set at $250^{\circ} \mathrm{C}$ and a split ratio of $10: 1$ ) through the transfer line maintained at $250^{\circ} \mathrm{C}$.

The GC column temperature was held at $50{ }^{\circ} \mathrm{C}$ for $2 \mathrm{~min}$ followed by a ramp-up of temperature to $250^{\circ} \mathrm{C}$ at a rate of $6{ }^{\circ} \mathrm{C} \mathrm{min}-1$. The split ratio was initially set to $10: 1$ for $0.75 \mathrm{~min}$, then $100: 1$ for $2.25 \mathrm{~min}$ and finally $20: 1$ till the end of the run. To avoid a "dead volume" signal in the chromatograph, the MS was set at a 5 min hold. The MS had a mass detection range of $35-300 \mathrm{~m} \mathrm{z}^{-1}$ and ran for the full duration of the GC program (35.33 min). Each sample was screened for 38 different compounds (see Table S1 and Fig. S1 in the Supplement).

Custom-made calibration standards were obtained from Supelco Analytical at a $1000 \mu \mathrm{g} \mathrm{L}^{-1}$ concentration dissolved in methanol. A five-point calibration curve was made for each compound by injecting five decreasing amounts of the standards into the CDS concentrator. Error or uncertainty of 
the sampling system was quantified through the accuracy, precision and detection limit. The following statistics were calculated based on spiked seawater samples subjected to the same purging analysis as the phytoplankton monocultures. Seawater was spiked with a known concentration of analytes, and purged through the CDS concentrator and GC/MS. A total of eight spiked seawater analyses were conducted. The relative \% error (RE) was computed as

$\mathrm{RE}=\left|\frac{(x-u)}{u}\right| \times 100$,

where $x$ is the measured analyte concentration and $u$ is the actual analyte concentration.

Accuracy was determined by averaging RE over the eight identical spiked seawater samples. Precision was determined by the relative standard deviation (RSD), which was computed as

$\mathrm{RSD}=\frac{\sum(x-\bar{x})^{2}}{N-1} \times 100$,

where $\bar{x}$ is the mean analyte concentration and $N$ is the number of analyses. The detection limit of an analytical system is normally determined by the lowest detected signal above a blank background within a $99 \%$ confidence interval, assuming a signal to noise $(S / N)$ ratio of 5 (WDNR, 1996). A blank run through the analytical system showed no discernible detection of the analytes above a $S / N$ of 5. An alternative detection limit calculation can be obtained by the method detection limit (MDL). The MDL is the minimum concentration of an analyte measured within a $99 \%$ confidence interval by repetitive samples of the analyte in the sample matrix (WDNR, 1996). Due to the fact that BVOC analysis includes a three-step process (purge and trap by the CDS concentrator, compound separation by the GC, and detection by the MS), a comprehensive MDL was calculated for each compound:

$\mathrm{MDL}=t_{(n-1,1-\infty=0.99)}(S)$,

where $t$ is the student $t$ value based on the number of analyses (8) at the $99 \%$ confidence level and $S$ is the standard deviation of the analyte concentration. For all analytes, the precision and accuracy are less than $20 \%$. The MDL ranges from 3.83 to 7.15 pptv. Table 1 summarizes compound attributes and error analyses for isoprene and monoterpene species.

\subsection{Purging analysis}

The water sample was bubbled inside the $250 \mathrm{~mL}$ purging vessels through a Mist Air $^{\circledR}$ glass air stone. The gas inlet to the vessel was attached to the blanket gas, while the outlet was attached to a purge and trap CDS concentrator. Each sample was purged for $35 \mathrm{~min}$ at a flow rate of $0.40 \mathrm{slpm}$. Following the purge, the monocultures were sealed and placed back in the water tank. The analysis was based on the principle of liberating BVOC from the water samples into the gas stream. To quantify the amount of BVOC recovered by the purging analysis, purging efficiencies were calculated separately for each compound and are reported in Table 1 . The purging efficiencies were calculated by spiking seawater with a known concentration of the standards. Successive purging steps from the same sample vial were performed until the compound concentrations were below the detection limit. The purging efficiency was calculated by taking the ratio of the initial purge BVOC concentrations divided by the sum of the BVOC concentrations over all the purging steps. The purging procedure was optimized for $>90 \%$ purging efficiency for isoprene and monoterpene species. Calculated purging efficiencies were comparable to values of $>90 \%$ and $>95 \%$ obtained by a similar analysis from Broadgate et al. (1997) and Shaw et al. (2003), respectively.

\subsection{Biological parameters}

At the end of each $12 \mathrm{~h}$ sampling period, $30 \mathrm{~mL}$ of each monoculture were filtered onto a Whatman GF/F filter. Chlorophyll $a$ (Chl $a$ ) was extracted from the filters with $90 \%$ acetone and the concentration was determined following the method of Holm-Hansen and Riemann (1978) using a Turner fluorometer model no. 450. For the light stress experiments, another $30 \mathrm{~mL}$ of each sample were analyzed for cell counts and size distributions of phytoplankton cultures. A Coulter ${ }^{\circledR}$ Sample Stand II connected to a COULTER COUNTER analyzer (Coulter Electronics, Inc., Hialeah, FL) was used to determine the number and size of particles that were suspended in seawater. Duplicates of both Chl $a$ and cell counts were taken for each sample container.

Precision was calculated for both Chl $a$ and cell counts from multiple runs of the same monoculture sample. Similarly to the BVOC calculation, eight replicate samples were conducted for both Chl $a$ and cell counts. The RSD for Chl $a$ and cell counts was 19.3 and $15.6 \%$, respectively.

\subsection{Production rate calculation}

The corrected analyte mass ( $\mu \mathrm{g})$ was calculated by dividing the measured mass $(\mu \mathrm{g})$ by the purging efficiency using the method similar to that of Shaw et al. (2003). To account for the possible presence of the analyte in a blank seawater sample or in autoclaved seawater after inoculation with the nutrient medium, a correction was applied by subtracting the purging efficiency normalized blank analyte mass from the corrected analyte mass. The analyte mass was therefore corrected for both purging efficiency and the background mass in seawater samples. To account for the residual or carry-over due to the incomplete purging of the compounds from each 
Table 1. Compound attributes and error analysis.

\begin{tabular}{llrrrrrrr}
\hline Compound & Formula & $\begin{array}{r}\text { Ret. time } \\
(\mathrm{min})\end{array}$ & $\begin{array}{r}\text { Quan ion } \\
\left(\mathrm{m} \mathrm{z}^{-1}\right)\end{array}$ & $\begin{array}{r}\text { Relative } \\
\text { error }(\%)\end{array}$ & $\begin{array}{r}\text { Relative standard } \\
\text { deviation }(\%)\end{array}$ & $\begin{array}{r}\text { MDL } \\
(\text { pptv })\end{array}$ & $\begin{array}{r}\text { Purging } \\
\text { efficiencies }(\%)\end{array}$ & $\begin{array}{r}\text { RSD } \\
\text { Total } \\
(\%)\end{array}$ \\
\hline Isoprene & $\mathrm{C}_{5} \mathrm{H}_{8}$ & 13.594 & 66.8 & 8.53 & 4.29 & 6.04 & 95.73 & 25.18 \\
$\alpha$-Pinene & $\mathrm{C}_{10} \mathrm{H}_{16}$ & 31.083 & 92.9 & 10.70 & 5.10 & 5.40 & 94.65 & 25.34 \\
$\beta$-Pinene & $\mathrm{C}_{10} \mathrm{H}_{16}$ & 31.835 & 93.1 & 17.43 & 14.78 & 7.15 & 91.28 & 28.89 \\
Camphene & $\mathrm{C}_{10} \mathrm{H}_{16}$ & 31.134 & 93.0 & 11.55 & 5.06 & 5.10 & 92.30 & 25.33 \\
d-Limonene & $\mathrm{C}_{10} \mathrm{H}_{16}$ & 34.072 & 67.0 & 12.60 & 12.61 & 3.83 & 93.70 & 27.84 \\
\hline
\end{tabular}

sample flask, the final analyte mass was calculated as

$$
\begin{aligned}
& \text { Final }=\begin{array}{l}
\text { blank corrected } \\
\text { analyte mass } \mathrm{P} 2
\end{array} \\
& -\left[(1-\text { purging efficiency }) \times \begin{array}{l}
\text { blank corrected } \\
\text { analyte mass P1 }
\end{array}\right],
\end{aligned}
$$

where $\mathrm{P} 1$ and $\mathrm{P} 2$ denote the purging step and $(1-$ purging efficiency) indicates the residual analyte that remained in the sample flask from the previous purging step.

The calculated final production rates for each trace gas were normalized by the incubation time (or the time between purging steps), the volume of the headspace and aqueous sample, and Chl $a$ and cell counts. The total uncertainty (RSD ${ }_{\text {Total }}$ ) of production rates for each BVOC was quantified using the following weighting calculation:

$\mathrm{RSD}_{\text {Total }}=\left[\left(\mathrm{RSD}_{i}\right)^{2}+\left(\mathrm{RSD}_{\mathrm{Chl} a / \mathrm{CC}}\right)^{2}\right]^{0.5}$,

where $\mathrm{RSD}_{\text {Total }}$ is the total uncertainty for each BVOC, $i$ stands for different BVOCs (i.e., isoprene and monoterpene compounds), $\mathrm{RSD}_{i}$ is the uncertainty for each compound (listed in Table 1), and $\mathrm{RSD}_{\mathrm{Chl} a / \mathrm{CC}}$ is the $19.3 \%$ uncertainty for Chl $a$ measurements or the $15.6 \%$ uncertainty for cell count measurements. These values were used to constrain the error bars for each production rate calculation per sample run.

\section{Results}

\subsection{Light stress}

\subsubsection{Isoprene production rates}

Figure 2 shows isoprene production rates as a function of time for different light intensities on two successive days. Since species response to stress can be related to changes in cellular chlorophyll content, we have chosen to use phytoplankton cell number as the base and Chl $a$ concentration as a supplement to normalize isoprene and monoterpene emission rates for these experiments (see Figs. 2 and S2 in the Supplement). Figure 2 shows that isoprene production rates increase as a function of light intensity on the first day for all six phytoplankton species examined in this study. This result is consistent with most previous studies (e.g., Shaw et al., 2010), suggesting that isoprene production in algae species is linked to photosynthetic activities. Isoprene production rates in four of the phytoplankton species (T. weiss., $T$. pseud., P. carter, and R. salina), excluding the two dinoflagelletes (i.e., P. minim. and $K$. brevis), also reveals a large increase within the first $4 \mathrm{~h}$ of the experiment, followed by a considerable fall (see Fig. 2). A particularly large increase by a factor of 4 was observed for the diatom species (Fig. 2a, b), followed by the prymnesiophyte and cryptophyte strains (Fig. 2c, d). The dinoflagellates (P. minim., K. bre$v i s)$ exhibited high isoprene production rates on initial exposure to high light without a lag period. After $4 \mathrm{~h}$, the isoprene production rates decreased for all species and remained constant for the rest of the $12 \mathrm{~h}$ sampling period. It should be noted that the enhancements in isoprene production rates are particularly pronounced for higher irradiance intensities (i.e., 420 or $900 \mu \mathrm{mol} \mathrm{m}^{-2} \mathrm{~s}^{-1}$ ). The highest isoprene production rates of $1.8 \times 10^{-17}$ and $1.5 \times 10^{-17} \mathrm{~g} \mathrm{cell}^{-1} \mathrm{~h}^{-1}$ (i.e., 31.5 and $\left.34.7 \mu \mathrm{g}(\mathrm{g} \mathrm{Chl} a)^{-1} \mathrm{~h}^{-1}\right)$ were recorded for $T$. weiss., and T. pseud., respectively, followed by $R$. salina., $P$. minim., P. carter, and $K$. brevis of $9.0 \times 10^{-18}, 8.9 \times 10^{-18}$, $6.0 \times 10^{-18}, 5.3 \times 10^{-18} \mathrm{~g} \mathrm{cell}^{-1} \mathrm{~h}^{-1}$ (i.e., $6.4,15.3,12.9$ and $\left.9.9 \mu \mathrm{g}(\mathrm{g} \mathrm{Chl} a)^{-1} \mathrm{~h}^{-1}\right)$, respectively. Recently, Bonsang et al. (2010) also reported similar light-intensitydependent isoprene production rates from some of the temperate diatom species, although the maximum intensity of $100 \mu \mathrm{mol} \mathrm{m}^{-2} \mathrm{~s}^{-1}$ for their simulated diurnal cycle is considerably lower compared to the irradiances used in this study. Overall, when averaged over the entire $12 \mathrm{~h}$ cycle, all species show a rapid increase in isoprene production at low irradiance levels $\left(<150 \mu \mathrm{mol} \mathrm{m}^{-2} \mathrm{~s}^{-1}\right)$, and a gradual increase at intermediate irradiance levels ( 150 to $420 \mu \mathrm{mol} \mathrm{m}^{-2} \mathrm{~s}^{-1}$ ) until the light saturated production rates were reached (see Fig. S3 in the Supplement).

Figure 2 reveals very different isoprene production rates for T. weiss., T. pseud., P. carter. and R. salina on the second day (after $12 \mathrm{~h}$ of the dark cycle). These species show generally higher isoprene production rates at the beginning of the experiment. Isoprene production rates for the diatoms are a factor of 5 higher compared to the first $2 \mathrm{~h}$ of day 1 , but comparable to the emission levels reached at the end of 

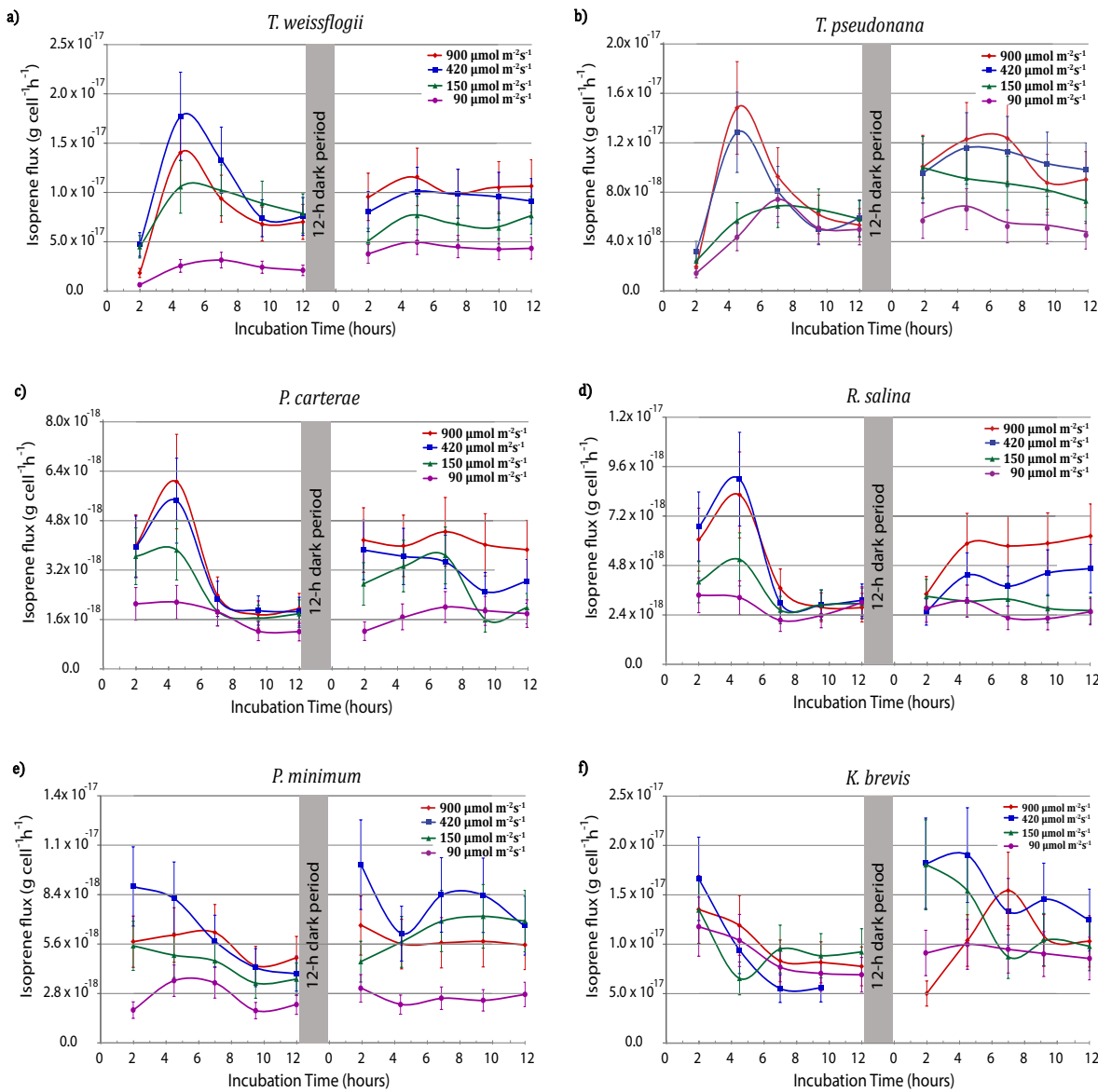

Figure 2. Light stress production rates for isoprene $\left(\mathrm{g}\right.$ cell $\left.{ }^{-1} \mathrm{~h}^{-1}\right)$ as a function of time during the first $(0$ to $12 \mathrm{~h})$ and second $(12$ to $24 \mathrm{~h})$ light cycles. Note that there was a $12 \mathrm{~h}$ dark period between the two five-point sample sets and that the first samples in each set were collected $2 \mathrm{~h}$ after lights on. Error bars denote the RSD Total value listed in Table 1.

the $12 \mathrm{~h}$ light cycle on the first day. Diatoms also do not reveal the light-saturated maximum rate in isoprene production characteristic of the first day. The cumulative production rates of isoprene for these species are generally higher during the second day compared to the first one (see Fig. S3). For the dinoflagellates (P. minim., and $K$. brevis), the second-day isoprene production rates exhibit patterns that more closely resemble those of the first $12 \mathrm{~h}$. Table 2 summarizes isoprene production rates from all six phytoplankton species at different irradiance levels averaged over a $12 \mathrm{~h}$ period on the first day.

\subsubsection{Monoterpene production rates}

Figure 3 shows phytoplankton production rates for $\alpha$-pinene, which was the highest of all monoterpene species examined in this study. Comparison of Figs. 2 and 3 shows that, for the first $12 \mathrm{~h}$ period, diatom production rates for isoprene and $\alpha$-pinene exhibit a considerable increase within the first $4 \mathrm{~h}$ of the experiment, followed by a decline. According to Fig. $3 \mathrm{a}$, b, the highest $\alpha$-pinene production rates in diatoms are 5.1 and $4.4 \times 10^{-19} \mathrm{~g} \mathrm{cell}^{-1} \mathrm{~h}^{-1}$ (i.e., 1.0 and $\left.1.1 \mu \mathrm{g}(\mathrm{g} \mathrm{Chl} a)^{-1}\right) \mathrm{h}^{-1}$ ) for T. weiss., and T. pseud., respectively, and are more than an order of magnitude lower compared to isoprene. Other strains (i.e., prymnesiophyte, dinoflagellate and cryptophyte) do not exhibit marked changes in $\alpha$-pinene production rates with time on day 1 (see Fig. 3c, d). During a second $12 \mathrm{~h}$ exposure on day 2, there was no increase in $\alpha$-pinene production rates for $T$. Weiss., while the rest of the algae species either showed considerable increases (i.e., T. pseud. and P. carter.) or exhibited few discernible differences. According to Fig. 3, $\alpha$-pinene production rates for $K$. brevis exhibit a considerable increase within the first $4 \mathrm{~h}$ of the light exposure on day 2. Increases in monoterpene emissions on day 2 seem to be common for K. brevis, as it was detected for all the monoterpenes measured in this study. Overall, when averaged over the entire $12 \mathrm{~h}$ cycle, $\alpha$-pinene production patterns are similar to those of isoprene, with a rapid increase at low irradiance levels $\left(<150 \mu \mathrm{mol} \mathrm{m}^{-2} \mathrm{~s}^{-1}\right)$ and with a gradual increase for intermediate irradiance levels (150 to $420 \mu \mathrm{mol} \mathrm{m}^{-2} \mathrm{~s}^{-1}$ ) until the light saturated production rates are reached (see Fig. S4 in the Supplement). 
Table 2. Isoprene and monoterpene production rates from phytoplankton monocultures averaged over a $12 \mathrm{~h}$ period on the first day.

\begin{tabular}{|c|c|c|c|c|c|c|c|c|c|c|c|c|c|c|c|c|c|c|c|c|c|c|c|c|}
\hline & \multicolumn{4}{|c|}{ T. weiss. } & \multicolumn{4}{|c|}{ T. pseud. } & \multicolumn{4}{|c|}{ P. carter. } & \multicolumn{4}{|c|}{ R. salina } & \multicolumn{4}{|c|}{ P. minim. } & \multicolumn{4}{|c|}{ K. brevis } \\
\hline & 900 & 420 & 150 & 90 & 900 & 420 & 150 & 90 & 900 & 420 & 150 & 90 & 900 & 420 & 150 & 90 & 900 & 420 & 150 & 90 & 900 & 420 & 150 & 90 \\
\hline & \multicolumn{4}{|c|}{$\mu \mathrm{mol} \mathrm{m}^{-2} \mathrm{~s}^{-1}$} & \multicolumn{4}{|c|}{$\mu \mathrm{mol} \mathrm{m}{ }^{-2} \mathrm{~s}^{-1}$} & \multicolumn{4}{|c|}{$\mu \mathrm{mol} \mathrm{m}^{-2} \mathrm{~s}^{-1}$} & \multicolumn{4}{|c|}{$\mu \mathrm{mol} \mathrm{m}^{-2} \mathrm{~s}^{-1}$} & \multicolumn{4}{|c|}{$\mu \mathrm{mol} \mathrm{m}^{-2} \mathrm{~s}^{-1}$} & \multicolumn{4}{|c|}{$\mu \mathrm{mol} \mathrm{m}^{-2} \mathrm{~s}^{-1}$} \\
\hline $\begin{array}{l}\text { Isoprene } \\
\mu \text { gram }(\mathrm{g} \mathrm{Chl} a)^{-1} \mathrm{~h}^{-1}\end{array}$ & 17.2 & 18.0 & 13.7 & 7.0 & 17.6 & 15.7 & 11.8 & 8.4 & 6.9 & 6.4 & 5.4 & 4.9 & 8.7 & 9.9 & 7.3 & 5.7 & 12.2 & 10.7 & 9.0 & 5.6 & 6.3 & 5.8 & 5.8 & 5.4 \\
\hline $\begin{array}{l}\text { Isoprene } \\
\times 10^{20} \text { moles }(\text { cell })^{-1} \mathrm{~h}^{-1}\end{array}$ & 11.5 & 14.9 & 12.3 & 3.18 & 10.9 & 10.2 & 7.96 & 6.75 & 4.67 & 4.46 & 3.70 & 2.46 & 6.90 & 7.23 & 5.16 & 4.14 & 8.01 & 9.10 & 6.49 & 3.75 & 4.08 & 4.75 & 3.91 & 3.60 \\
\hline $\begin{array}{l}\alpha \text {-Pinene } \\
\times 10 \mu \operatorname{gram}(\mathrm{g} \mathrm{Chl} a)^{-1} \mathrm{~h}^{-1}\end{array}$ & 4.65 & 5.57 & 3.84 & 1.32 & 5.51 & 5.68 & 3.52 & 2.19 & 2.91 & 2.84 & 2.33 & 1.64 & 2.69 & 4.19 & 4.64 & 2.99 & 3.99 & 3.98 & 2.93 & 2.03 & 5.99 & 5.37 & 4.01 & 2.97 \\
\hline $\begin{array}{l}\alpha \text {-Pinene } \\
\times 10^{21} \text { moles }(\text { cell })^{-1} \mathrm{~h}^{-1}\end{array}$ & 1.55 & 2.31 & 1.73 & 0.30 & 1.71 & 1.84 & 1.21 & 0.88 & 1.00 & 0.99 & 0.81 & 0.41 & 1.06 & 1.52 & 1.74 & 1.09 & 1.31 & 1.70 & 1.05 & 0.60 & 1.93 & 2.22 & 1.35 & 0.99 \\
\hline $\begin{array}{l}\text { Camphene } \\
\times 100 \mu \operatorname{gram}(\mathrm{g} \mathrm{Chl} a)^{-1} \mathrm{~h}^{-1}\end{array}$ & 0.66 & 1.66 & 0.28 & 0.75 & 1.07 & 0.41 & 1.86 & 0.15 & 0.74 & 0.72 & 0.45 & 0.23 & 0.52 & 0.76 & 0.41 & 0.29 & 1.20 & 0.44 & 0.82 & 1.07 & 0.82 & 0.81 & 0.60 & 0.52 \\
\hline $\begin{array}{l}\text { Camphene } \\
\left.\times 10^{22} \text { moles (cell) }\right)^{-1} \mathrm{~h}^{-1}\end{array}$ & 2.20 & 2.23 & 1.27 & 1.35 & 3.30 & 1.33 & 3.12 & 0.59 & 1.97 & 1.51 & 0.75 & 0.58 & 1.71 & 2.76 & 1.55 & 0.90 & 3.10 & 1.54 & 2.94 & 3.55 & 2.18 & 3.33 & 1.65 & 0.76 \\
\hline $\begin{array}{l}\beta \text {-Pinene } \\
\times 100 \mu \operatorname{gram}(\mathrm{g} \mathrm{Chl} a)^{-1} \mathrm{~h}^{-1}\end{array}$ & 2.54 & 4.36 & 3.34 & 7.44 & 7.98 & 12.2 & 4.15 & 6.02 & 5.66 & 4.65 & 0.57 & 1.82 & 1.14 & 2.27 & 4.09 & 2.02 & 1.25 & 1.82 & 1.59 & 2.65 & 0.91 & 1.25 & 1.02 & 0.68 \\
\hline $\begin{array}{l}\beta \text {-Pinene } \\
\times 10^{22} \text { moles }(\text { cell })^{-1} \mathrm{~h}^{-1}\end{array}$ & 0.85 & 1.81 & 1.51 & 1.69 & 2.47 & 3.95 & 2.01 & 2.43 & 1.93 & 1.62 & 0.21 & 0.57 & 0.47 & 0.82 & 1.54 & 0.73 & 0.41 & 0.77 & 0.56 & 0.90 & 0.28 & 0.53 & 0.36 & 0.24 \\
\hline $\begin{array}{l}\text { d-Limonene } \\
\times 10 \mu \text { gram }(\mathrm{g} \mathrm{Chl} a)^{-1} \mathrm{~h}^{-1}\end{array}$ & 3.61 & 4.86 & 1.67 & 0.41 & 1.66 & 5.04 & 2.13 & 0.42 & 0.77 & 1.16 & 1.94 & 0.36 & 1.17 & 1.37 & 0.76 & 1.18 & 3.46 & 5.20 & 2.45 & 1.99 & 1.96 & 1.61 & 1.86 & 0.88 \\
\hline $\begin{array}{l}\text { d-Limonene } \\
\times 10^{22} \text { moles }(\text { cell })^{-1} \mathrm{~h}^{-1}\end{array}$ & 12.1 & 20.0 & 7.50 & 0.93 & 5.15 & 13.1 & 8.71 & 1.70 & 2.62 & 4.02 & 6.72 & 0.91 & 4.63 & 5.02 & 2.84 & 4.32 & 11.4 & 17.7 & 8.77 & 6.60 & 6.34 & 6.66 & 6.27 & 2.90 \\
\hline
\end{tabular}
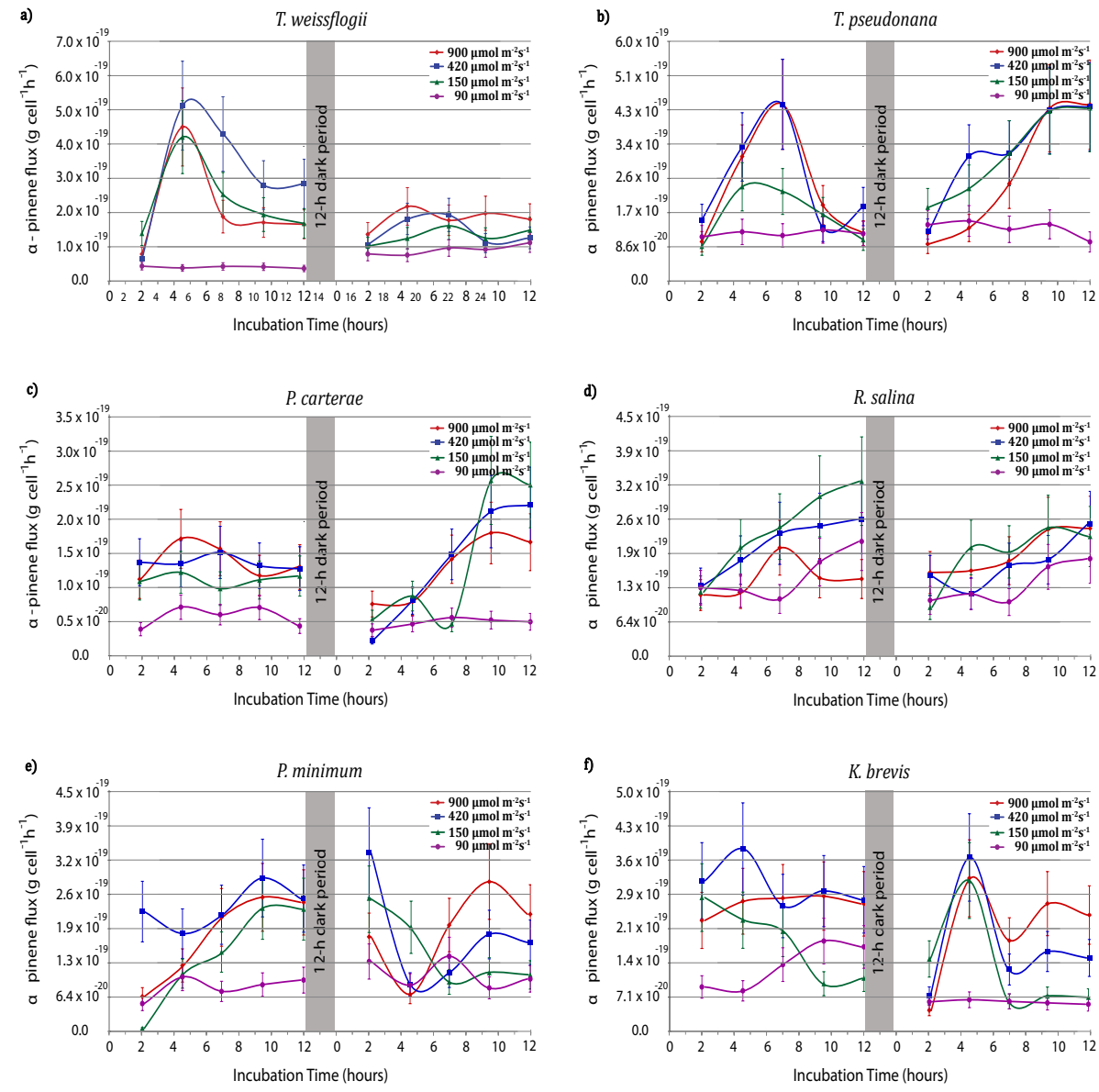

Figure 3. Light stress production rates for $\alpha$-pinene $\left(\mathrm{g} \mathrm{cell}^{-1} \mathrm{~h}^{-1}\right)$ as a function of time during the first $(0$ to $12 \mathrm{~h})$ and second $(12$ to $24 \mathrm{~h})$ light cycles. Note that there was a $12 \mathrm{~h}$ dark period between the two five-point sample sets and that the first samples in each set were collected

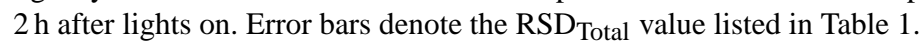


Emission patterns of d-limonene, camphene and $\beta$-pinene (not shown) were similar to that of $\alpha$-pinene, but at considerably lower rates. Although monoterpene species were detected at all levels (with enhanced rates for higher levels of irradiance), very low emission rates made detection sporadic. For example, $\beta$-pinene was present at some purging steps, but not others. Table 2 summarizes $12 \mathrm{~h}$ averaged monoterpene production rates from six phytoplankton species at different irradiance levels. According to Table 2, the average contribution to the total monoterpene production for all phytoplankton species was $\sim 70 \%$ from $\alpha$-pinene, $\sim 20 \%$ for $\mathrm{d}$-limonene, and $<10 \%$ for camphene and $\beta$-pinene. Compared to isoprene, total terpene emission was an order of magnitude lower for all phytoplankton species at all light levels (see Table 2).

\subsection{Temperature and light stress}

\subsubsection{Isoprene production rates}

Temperature dependence of isoprene emissions has been noted for both terrestrial and marine photosynthetic organisms. Increasing temperature was shown to enhance isoprene emissions to a maximum production rate until a certain temperature is reached, beyond which further increases in temperature were shown to cause a decline in isoprene emissions (Guenther et al., 1993; Harley et al., 1996; Shaw et al., 2003). As mentioned above, bulk cultures in this study were acclimated to an irradiance intensity of $90 \mu \mathrm{mol} \mathrm{m}^{-2} \mathrm{~s}^{-1}$ and $22{ }^{\circ} \mathrm{C}$. So, any temperature and/or irradiance levels different from these values are expected to cause short- and long-term changes to the plankton photosystem intended to establish balanced growth. The effects of such changes on isoprene production by algae species are explored below.

Temperature- and light-dependent experiments were conducted for the two diatom species, T. weiss. and T. pseud., and samples were averaged over two successive $12 \mathrm{~h}$ cycles. Such a long averaging time does not allow monitoring of short-term responses of phytoplankton to temperature and light stresses. Also, due to the absence of the cell count data, all flux values are normalized with respect to Chl $a$, which may change due to photoacclimation. Nevertheless, Fig. 4 shows some interesting features for isoprene production rates. According to Fig. 4, under the low irradiance regime (i.e., $\leq 90 \mu \mathrm{mol} \mathrm{m}{ }^{-2} \mathrm{~s}^{-1}$ ), temperature variability has a minor effect on isoprene production for two diatom species. Isoprene emission rates by $T$. weiss. and $T$. pseud. tend to be lower at $18^{\circ} \mathrm{C}$ for all light levels. Emissions increase, with the temperature reaching its highest levels around 22 to $26^{\circ} \mathrm{C}$. Further increases in temperature cause a considerable decline in isoprene production rates. However, careful inspection of Fig. 4 shows that temperature can influence isoprene production rates in diatoms exposed to the high irradiance regime (i.e., $\geq 150 \mu \mathrm{mol} \mathrm{m}^{-2} \mathrm{~s}^{-1}$ ). Figure 4 also shows differences in the $12 \mathrm{~h}$ averaged isoprene production rate be- tween the two successive days. For T. pseud., the maximum production rate on the first day is reached at $22^{\circ} \mathrm{C}$ for all irradiance levels while, on the second day, the production rate peaked at $26^{\circ} \mathrm{C}$ for lower irradiance levels (i.e., below $150 \mu \mathrm{mol} \mathrm{m}{ }^{-2} \mathrm{~s}^{-1}$ ) and at $22^{\circ} \mathrm{C}$ for higher irradiance levels (i.e., above $150 \mu \mathrm{mol} \mathrm{m} \mathrm{m}^{-2} \mathrm{~s}^{-1}$ ). Overall, Fig. 4 shows that, for all temperature and light levels, higher isoprene production rates are reached on the second day. A similar conclusion was previously reached for isoprene production as a function of light stress only (see Sect. 3.1.1). Table 3 summarizes $12 \mathrm{~h}$ averaged isoprene production rates for two diatom species at different temperature and irradiance levels.

\subsubsection{Monoterpene production rates}

Unlike isoprene, monoterpenes in terrestrial vegetation can be stored in leaves and be released relatively quickly on a timescale of minutes to hours. Monoterpene emitting terrestrial vegetation has been found to have a higher temperature than light dependencies (Koppmann and Wildt, 2007). If something similar was true for phytoplankton, one would expect enhanced monoterpene emission rates for temperatures higher than $22^{\circ} \mathrm{C}$ (the temperature at which species were acclimated) with emission patterns distinct from those of isoprene.

Figure 5 shows that $12 \mathrm{~h}$ averaged $\alpha$-pinene emission on two successive days is similar to that of isoprene (see Fig. 4), although at considerably lower rates. For $T$. weiss., $\alpha$-pinene production rates for both days are highest at $26^{\circ} \mathrm{C}$. For $T$. pseud., $\alpha$-pinene production rates peak at a lower temperature $\left(22^{\circ} \mathrm{C}\right)$ at irradiance levels $\geq 150 \mu \mathrm{mol} \mathrm{m}^{-2} \mathrm{~s}^{-1}$. Table 3 summarizes $12 \mathrm{~h}$ averaged monoterpene production rates for two diatom species at different temperature and irradiance levels.

\section{Discussion}

A large number of recent studies have attempted to elucidate the mechanisms as well as the purpose behind the formation and emission of isoprene and monoterpenes from terrestrial plants. Despite this, the biological as well as ecological role and evolutionary aspect for the production of these BVOCs by vascular plants is not fully understood. Even less is known about their emissions from phytoplankton. However, as both isoprene and monoterpenes are formed in primary producers as a by-product of photosynthetic metabolism, to explain our findings, we will take a reductionist approach and presume similarities in isoprene and monoterpene biosynthesis between better known terrestrial vegetation and lesser known phytoplankton. Production of isoprene and monoterpenes in plants proceeds through a methylerythritol phosphate (MEP) metabolic pathway that is strongly tied to photosynthesis of primary producers through chlorophyll and carotenoid synthesis (Lichtenthaler, 2009). Lichtenthaler (1999) provided 
Table 3. Isoprene and monoterpene production rates from phytoplankton monocultures averaged over a $12 \mathrm{~h}$ period on the first day*

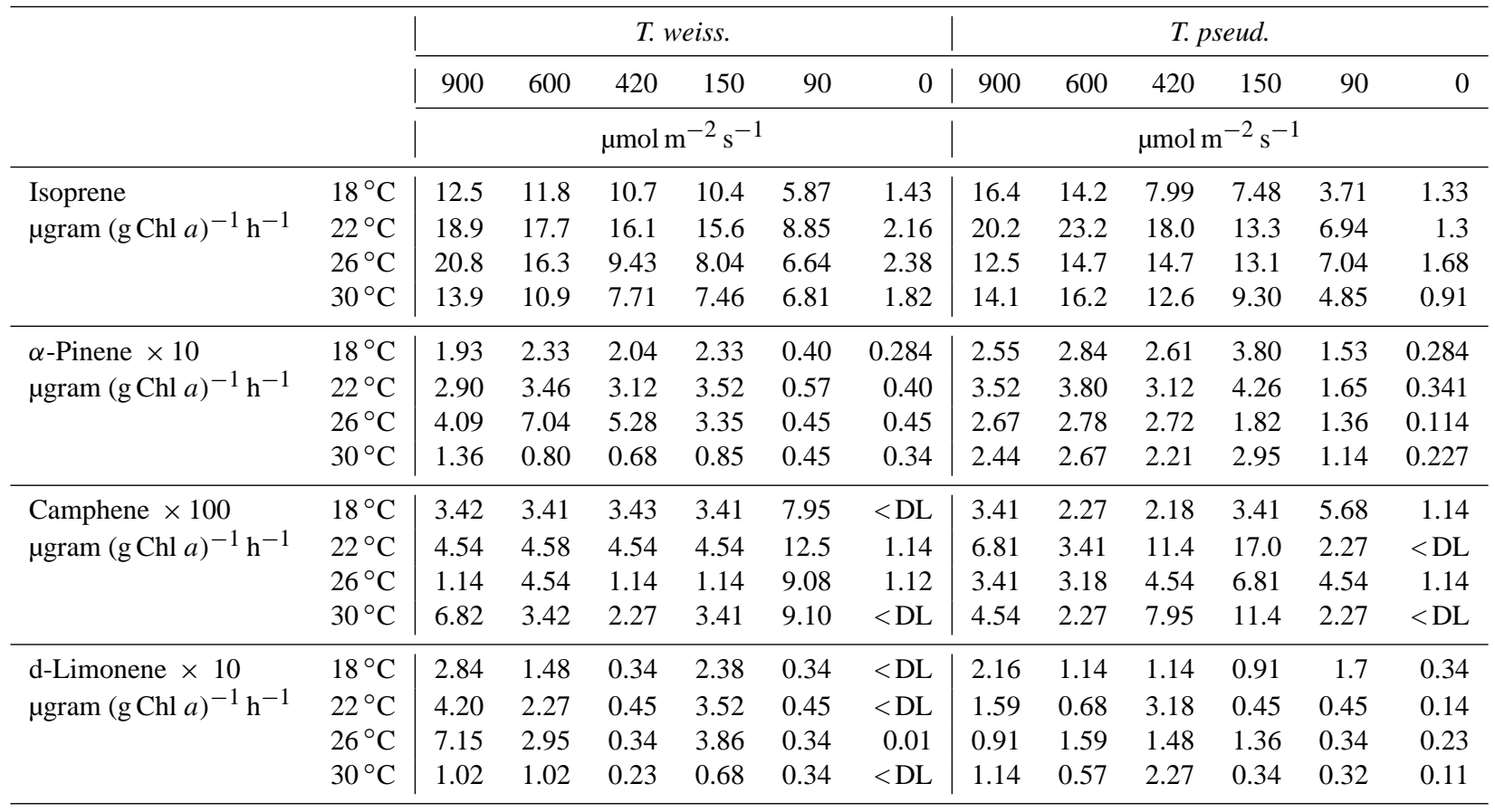

* DL - detection limit
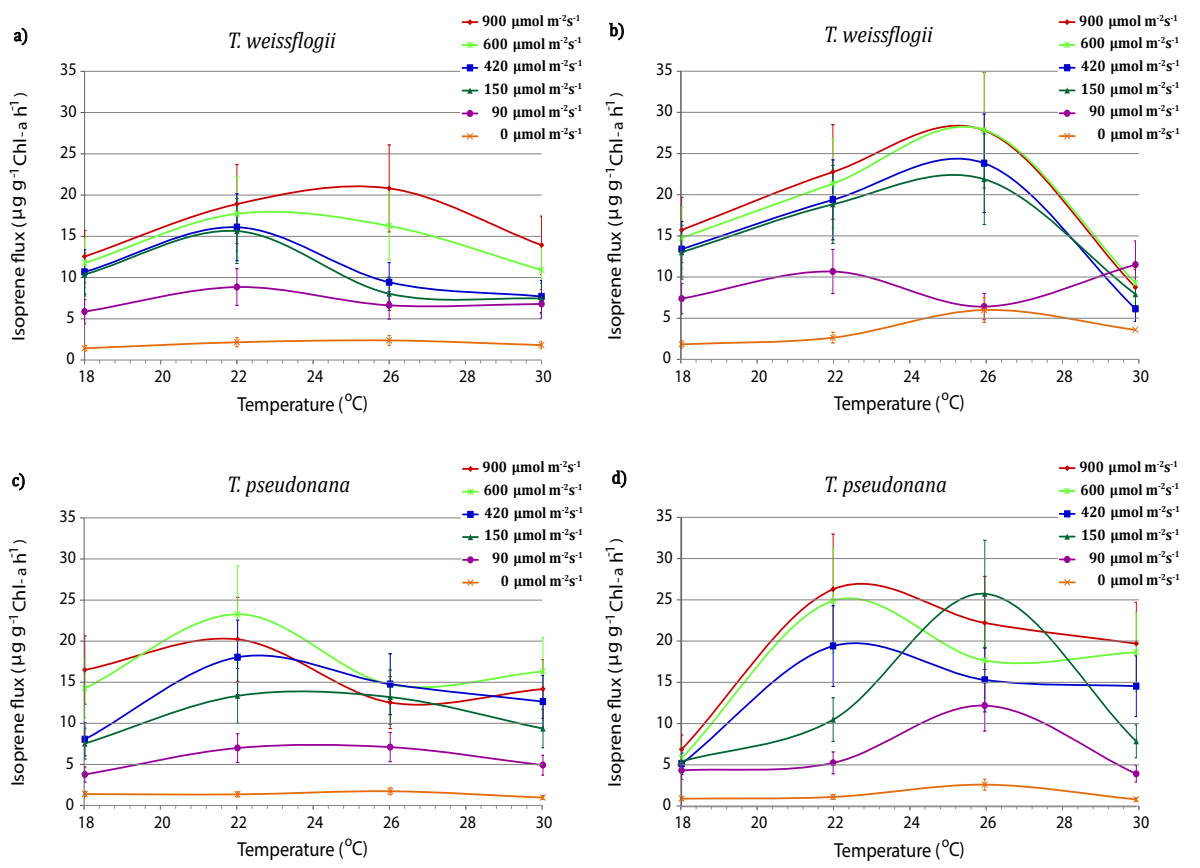

Figure 4. The $12 \mathrm{~h}$ averaged isoprene production rates $\left(\mu \mathrm{g}(\mathrm{gChl} a)^{-1} \mathrm{~h}^{-1}\right)$ for the first (left column) and second (right column) light cycles as a function of temperature. Error bars denote the RSD Total value listed in Table 1.

a detailed description of the MEP pathway, where a chain of enzymatic processes leads to the formation of dimethylallyl diphosphate (DMAPP) and isopentenyl diphosphate (IPP). DMAPP then through isoprene synthase can lead to isoprene formation, while both DMAPP and IPP can form monoterpene species. Production and expulsion of isoprene and monoterpenes from primary producers is very energy costly (Sharkey and Yeh, 2001). The basic hypothesis is that 

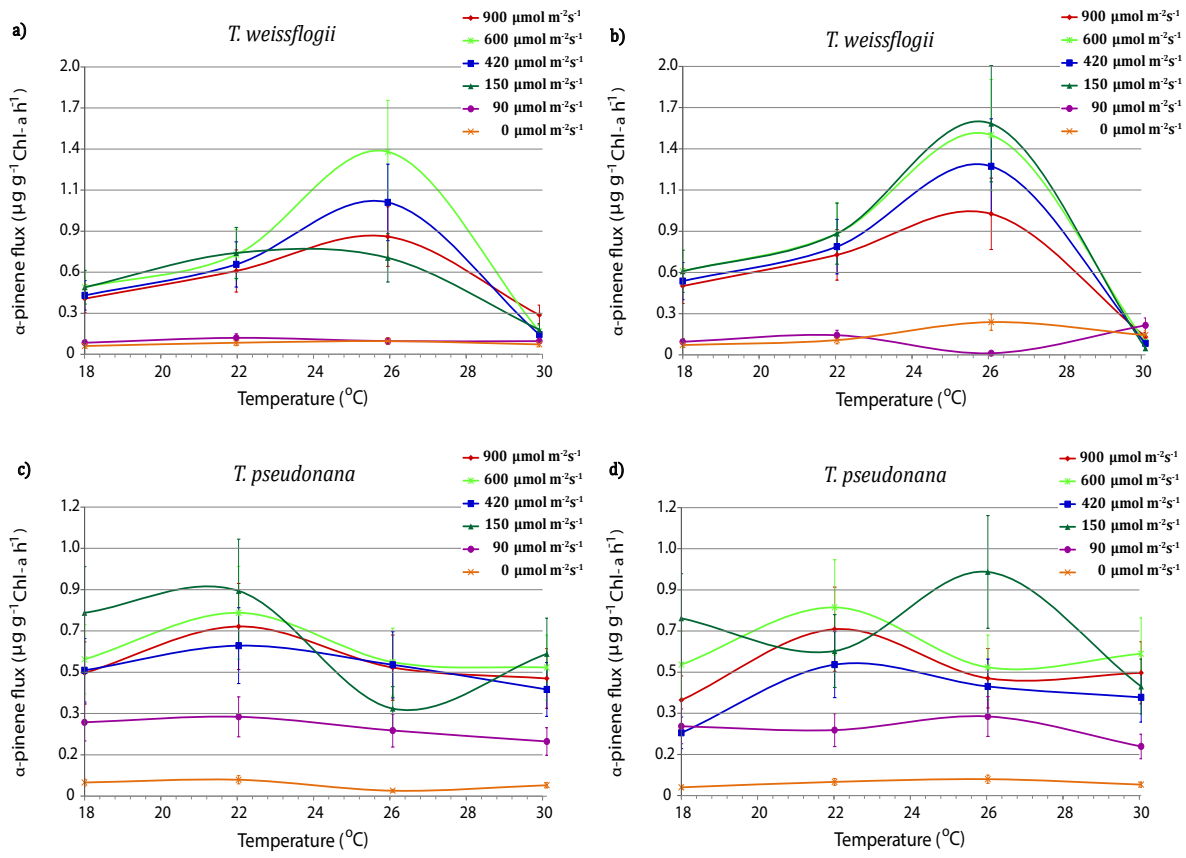

Figure 5. The $12 \mathrm{~h}$ averaged $\alpha$-pinene production rates $\left(\mu \mathrm{g}(\mathrm{gChl} a)^{-1} \mathrm{~h}^{-1}\right)$ for the first (left column) and second (right column) light cycles as a function of temperature. Error bars denote the RSD Total value listed in Table 1.

there is an advantage to gain by photosynthesizing organisms to emit isoprene. Some advantages in terrestrial plants include thermotolerance, use as an anti-oxidant from atmospheric oxidants like ozone, an energy "release valve" or a mechanism to get rid of unwanted metabolites or energy, flowering response, and insect defense (Sharkey et al., 2008). Unlike isoprene that is not stored within the leaf and is emitted as soon as it is formed (Delwiche and Sharkey, 1993), many terrestrial plants have special storage organelles either in leaf-internal structures (e.g., secretory cavities and secretory canals or ducts) or in structures located on the surface of the leaf (e.g., trichomes) where monoterpenes can be stored. Other parameters such as light, drought, and herbivore attack can also affect the monoterpene emissions from terrestrial vegetation, though the emission rate has been shown to increase exponentially with leaf temperature (Koppmann and Wildt, 2007).

Similar to vascular plants, phytoplankton attempt to find a balance between energy from light reactions in chloroplasts and the energy used for metabolic processes and carbon fixation (Geider et al., 1996). Perturbations under different environmental conditions (e.g., light and temperature) can disturb the balance in chloroplasts and force primary producers to adjust or acclimate physiologically (Cullen and Lewis, 1988; Huner et al., 1998). For a short-term modulation of energy flow to the photosynthetic reaction centers, accessory pigments in plants can help dissipate excessive photon flux (nonphotochemical quenching) on the timescale of minutes (MacIntyre et al., 2002). When the short-term responses are insuf- ficient for dealing with prolonged changes in light, longerterm responses (on the order of hours or days) to high irradiances can include the reduction in the quantum efficiency of photosystems by a decline in Chl $a$, the light harvesting antennae, and accessory pigments, as well as a decrease in the number of photosystem reaction centers and changes in electron transfer chain components and Calvin cycle enzymes (MacIntyre et al., 2002). Photoacclimation is complete when a condition of "balanced" growth has been achieved (Geider et al., 1996). Results from the first day of the experiment seem to be consistent with this picture. For the experimental irradiances above $150 \mu \mathrm{mol} \mathrm{m} \mathrm{m}^{-2} \mathrm{~s}^{-1}$ (that well exceeded the $90 \mu \mathrm{mol} \mathrm{m}^{-2} \mathrm{~s}^{-1}$ at which species were acclimated), two diatoms, primnesiophyte, and cryptophyte strains showed large increases in the production rates of isoprene and monoterpenes within the first $4 \mathrm{~h}$ of the experiment. This result indicates that initial pigment adjustment, related to the xanthophyll cycle or other non-photochemical quenching, was not enough to dissipate the excess energy, and the balance between the photosynthetic reaction centers was disrupted; i.e., species experienced initial photoinhibition. After several hours, the photoacclimation of species caused a sharp reduction in isoprene and monoterpene emission rates. It should be noted that the two dinoflagellates showed a different pattern in BVOC production that may be related either to the mechanical stress on phytoplankton from bubbling of air through the sample and/or to differences in photoacclimation response. Previous work has shown that mechanical stress, by sparging or shaking dinoflagellate cells, can 
cause an increase in BVOC emissions (Wolfe et al., 2002). Different methods for the partitioning of BVOCs into the headspace may be needed to avoid the shear stress on the dinoflagellates caused by the air bubbling. Past studies have also revealed interspecific variability in quantum efficiency of photosynthesis between different algae species acclimated under the same conditions. The lowest values of quantum efficiency were reported for dinoflagellates, while the highest values were found in diatoms (Langdon, 1988).

On the second day of the experiment, species showed higher and relatively steady BVOC emission rates compared to the first day. As production of isoprene and monoterpenes is directly related to the cell metabolism, elevated emission rates at higher light levels may simply indicate a delayed adjustment in dark reactions. The $\mathrm{Chl} a$ to cell number ratio for cultures was generally lower on the second day compared to the first one, suggesting the reduction in the Chl $a$ synthesis rate as part of the species' photoacclimation process. Elevated emission rates on day 2 may also suggest that the photoresponse mechanism applied during the first day was associated with chlorophyll decline and that the second-day exposure required a continued adjustment in dark reactions to re-establish long-term photoacclimation. Overall, the results suggest that 2 days were not sufficient for the tested species to attain steady-state photoacclimation to the imposed light changes and that longer experiments may be needed to describe isoprene and monoterpene production fully over the full photoacclimation period (Geider et al., 1996). These results also suggest that future studies in this area should report emission rates normalized to cell number as well as Chl $a$.

Although temperature is perhaps one of the most important environmental factors that influences algal growth rate, cell size, biochemical composition and nutrient requirements, our measurements with simultaneous occurrences of elevated light and temperature levels show that temperature variability alone has a minor effect on isoprene and monoterpene production rates from the phytoplankton. Previous studies of marine cyanobacteria acclimated to a different temperature over the entire range for growth did not reveal a clear relationship between isoprene emission rates and temperature, leading to the suggestion that, unlike terrestrial plants, phytoplankton are exposed to more stable and lower temperatures on average, and would not need to emit isoprene for thermal protection (Shaw et al., 2003). However, our results suggest that, when combined with the light stress, temperature stress can influence isoprene and monoterpene emissions from phytoplankton. Based on our results, BVOC emission patterns for dual (temperature and light) stress conditions can be clustered in three major regions. For temperatures lower than the one at which phytoplankton was acclimated, production rates of isoprene and monoterpenes are consistently lower for all light levels examined in this study. Such behavior is in agreement with exponential reduction of specific growth rates of algae cultures suggested by Eppley (1972) related to a $Q_{10}$ temperature relationship. Lower temperatures also cause an increase in the levels of unsaturated fatty acids inside the cell, making the membranes more susceptible to damage by free radicals (Juneja et al., 2013). Increasing temperatures beyond the species' tolerance induces the marked reduction in the growth rate (Boyd et al., 2013). Both diatoms examined in this study reveal consistently lower BVOC emission rates at $30^{\circ} \mathrm{C}$. Discrepancies between T. weiss. and T. pseud. are likely to be associated with species- and strain-specific levels of supraoptimal temperatures (Juneja et al., 2013). In between two temperature extremes, isoprene and monoterpene emission rates reveal complex patterns that cannot be easily interpreted, but that probably are related to variable species-specific imbalances between light and dark reactions (Geider et al., 1996). Since simultaneous occurrences of elevated ocean temperature and stratification are among the most likely phenomena associated with global change, additional measurements (including time-dependent fluxes of BVOC under temperature and light stress conditions) need to be conducted for both acclimated and instantaneous environmental responses. Real ocean phytoplankton populations will encounter and will respond to both short-term (vertical mixing) and long-term (interannual increases) exposures to altered global climate change environments.

Despite large discrepancies in emission rates, the great similarity between emission patterns of isoprene and monoterpenes revealed in this study suggests that monoterpenes - like isoprene - may be emitted from phytoplankton as soon as they are produced. Shipboard measurements during a field campaign in the southern Atlantic Ocean also revealed a positive correlation $\left(R^{2}=0.57\right)$ between $\alpha$-pinene and isoprene within the bloom region (Yassaa et al., 2008).

\section{Conclusions}

In this study, we quantified production of isoprene and four different monoterpene compounds ( $\alpha$-pinene, $\beta$-pinene, camphene and d-limonene) from six phytoplankton monocultures as a function of different irradiance and temperature regimes. Our measurements confirmed that both isoprene and monoterpene production from marine algae can be influenced by variability in light and temperature. Isoprene and monoterpene emission patterns were similar regardless of whether production rates were normalized by cell number or Chl $a$ concentration. Emission rates were found to increase sharply when low-light acclimated phytoplankton were subject to higher irradiances of up to $900 \mu \mathrm{mol} \mathrm{m}^{-2} \mathrm{~s}^{-1}$, reaching the maximum isoprene and sum of all monoterpene production rates of $\sim 25$ and $\sim 1.5 \mu \mathrm{g}(\mathrm{g} \mathrm{Chl} a)^{-1} \mathrm{~s}^{-1}$, respectively, for diatom species. On average, it was found that the contribution to the total monoterpene production for all phytoplankton examined here was $\sim 70 \%$ from $\alpha$-pinene, $\sim 20 \%$ for d-limonene, and $<10 \%$ for camphene and $\beta$ pinene. Production rates were found to increase sharply starting at $150 \mu \mathrm{mol} \mathrm{m}^{-2} \mathrm{~s}^{-1}$, and continued at a higher rate up to 
$900 \mu \mathrm{mol} \mathrm{m} \mathrm{m}^{-2} \mathrm{~s}^{-1}$. This result is consistent with most previous studies, suggesting that isoprene and monoterpene production from phytoplankton is linked to photosynthetic activities. However, unlike previous studies that examined timeaveraged BVOC emission rates from phytoplankton subject to temperature and light regimes different from the one at which bulk cultures were incubated, here we explore timedependent emissions over two successive days. Moreover, this study explored phytoplankton response to the joint effect of variable light and temperature conditions.

To our knowledge, this is the first work that has explored isoprene and monoterpene production rates from microalgae species as a function of both step changes in light and temperature over 2 days, making it difficult to compare our results with other studies. Despite this, we believe that results presented in this study contribute to understanding the physiology behind the production of BVOCs by marine algae. For BVOCs examined in this study, air-sea exchange is the dominant loss term at all oceanic latitudes due to their low Henry law constants (e.g., Palmer and Shaw, 2005; Gantt et al., 2009). Therefore, experimental results presented here can lead to improved prediction of changes in natural emissions and help to understand variability in the abundance and spatial distribution of different algae species under changing environmental conditions. As changes in isoprene and monoterpene production were suggested to be associated with sequential responses to photoinhibition experienced over an extended time period, experimental length needs to be extended to more than 2 days to determine if prolonged exposure to altered light and temperature conditions would result in reduction of isoprene and monoterpene production once photoacclimation is complete. Future studies should also assess the effect of growth phase (Kameyama et al., 2011) on BVOC production rates from various phytoplankton species. The experiments should also be rerun using the same phytoplankton species and experimental conditions to check the repeatability of the results. Finally, in addition to light intensity and temperature, future studies should also examine the effects of $\mathrm{CO}_{2}$ levels, seawater $\mathrm{pH}$, nutrient availability, and the presence of other organisms on isoprene and monoterpene production from phytoplankton.

\section{The Supplement related to this article is available online at doi:10.5194/bg-12-637-2015-supplement.}

Acknowledgements. This research was supported by the Office of Science (BER), US Department of Energy, grant no. DE-FG0208ER64508, and the National Science Foundation through grants ATM-0826117 and AGS-1249273. A. Sabolis also acknowledges support from the North Carolina Space Grant Graduate Research Fellowship.

Edited by: K. Suzuki

\section{References}

Acuña-Alvarez, L. I., Exton, D. A., Timmis, K. N., Suggett, D. J., and McGenity, T. J.: Characterization of marine isoprene-degrading communities, Env. Microbiol., 11, 32803291, doi:10.1111/j.1462-2920.2009.02069.x, 2009.

Blanchard, D. C.: Sea-to-air transport of surface active material, Science, 146, 396-397, doi:10.1126/science.146.3642.396, 1964.

Bonsang, B., Polle, C., and Lambert, G.: Evidence for marine production of isoprene, Geophys. Res. Lett., 19, 1129-1132, 1992.

Bonsang, B., Gros, V., Peeken, I., Yassaa, N., Bluhm, K., Zoellner, E., Sarda-Esteve, R., and Williams, J.: Isoprene emission from phytoplankton monocultures, relationship with chlorophyll, cell volume, and carbon content, Environ. Chem., 7, 554-563, doi:10.1071/EN09156, 2010.

Bouvet, M., Hoepffner, N., and Dowell, M. D.: Parameterization of a spectral solar irradiance model for the global ocean using multiple satellite sensors, J. Geophys. Res., 107, 3215, doi:10.1029/2001JC001126, 2002.

Boyd, P. W., Rynearson, T. A., Armstrong, E. A., Fu, F., Hayashi, K., Hu, Z., Hutchins, D. A., Kudela, R. M., Litchman, E., Mulholland, M. R., Passow, U., Strzepek, R. F., Whittaker, K. A., Yu, E., and Thomas, M. K.: Marine Phytoplankton Temperature versus Growth Responses from Polar to Tropical Waters - Outcome of a Scientific Community-Wide Study, PLoS ONE, 8, e6309, doi:10.1371/journal.pone.0063091, 2013.

Broadgate, W. G., Malin, G., Kupper, F. C., Thompson. A., and Liss, P. S.: Isoprene and other non-methane hydrocarbons from seaweeds: a source of reactive hydrocarbons to the atmosphere, Mar. Chem., 88, 61-73, doi:10.1016/j.marchem.2004.03.002, 2004.

Broadgate, W. J., Liss, P. S., and Penkett, S. A.: Seasonal emissions of isoprene and other reactive hydrocarbon gases from the ocean, Geophys. Res. Lett., 24, 2675-2678, 1997.

Carpenter, L. J., Archer, S. D., and Beale, R.: Ocean-atmosphere trace gas exchange, Chem. Soc. Rev., 41, 6473-6506, doi:10.1039/C2CS35121H, 2012.

Carslaw, K. S., Lee, L. A., Reddingtonet, C. L., Pringle, K. J., Rap, A., Forster, P. M., and Mann, G.: Large contribution of natural aerosols to uncertainty in indirect forcing, Nature, 503, 67-71, doi:10.1038/nature12674, 2013.

Cermeño, P., de Vargas, C., Abrantes, F., and Falkowski, P. G.: Phytoplankton Biogeography and Community Stability in the Ocean, PLoS ONE 5, e10037, doi:10.1371/journal.pone.0010037, 2010.

Charlson, R. J., Lovelock, J. E., Andreae, M. O., and Warren, S. G.: Oceanic phytoplankton, atmospheric sulphur, cloud albedo and climate, Nature, 326, 655-661, 1987.

Cullen, J. J. and Lewis, M. R.: The kinetics of algal photoadaptation in the content of vertical mixing, J. Plankton Res., 10, 10391063, 1988.

de Leeuw, G., Andreas, E. L., Anguelova, M. D., Fairall, C. W., Lewis, E. R., O'Dowd, C., Schulz, M., and Schwartz, S. E.: Production flux of sea spray aerosol, Rev. Geophys., 49, RG2001, doi:10.1029/2010RG000349, 2011.

Delwiche, C. F. and Sharkey, T. D.: Rapid appearance of ${ }^{13} \mathrm{C}$ in biogenic isoprene when ${ }^{13} \mathrm{CO}_{2}$ is fed to intact leaves, Plant Cell Environ., 16, 587-591, 1993.

Eppley, R. W.: Temperature and phytoplankton growth in the sea, Fish. B.-NOAA, 70, 1063-1085, 1972. 
Exton, D. A., Suggett, D. J., McGenity, T. J., and Steinke, M.: Chlorophyll-normalized isoprene production in laboratory cultures of marine microalgae and implications for global models, Limnol. Oceanogr., 58, 1301-1311, doi:10.4319/lo.2013.58.4.1301, 2013.

Gantt, B., Meskhidze, N., and Kamykowski, D.: A new physicallybased quantification of marine isoprene and primary organic aerosol emissions, Atmos. Chem. Phys., 9, 4915-4927, doi:10.5194/acp-9-4915-2009, 2009.

Gantt, B., Meskhidze, N., Zhang, Y., and Xu, J.: The effect of marine isoprene emissions on secondary organic aerosol and ozone formation in the coastal United States, Atmos. Environ., 44, 115121, doi:10.1016/j.atmosenv.2009.08.027, 2010a.

Gantt, B., Meskhidze, N., and Carlton, A. G.: The contribution of marine organics to the air quality of the western United States, Atmos. Chem. Phys., 10, 7415-7423, doi:10.5194/acp-10-74152010, 2010b.

Geider, R. J., MacIntyre, H. L., and Kana, T.: A dynamic model of photoacclimation in phytoplankton, Limnol. Oceanogr., 41, 115, 1996.

Grime, J. P.: The stress debate: symptom of impending synthesis?, Biol. J. Linn. Soc., 37, 3-17, 1989.

Guenther, A. B., Zimmerman, P. R., and Harley, P. C.: Isoprene and monoterpene emission rate variability: model evaluations and sensitivity analysis, J. Geophys. Res., 98, 12609-12617, 1993.

Harley, P., Deem, G., Flint, S., and Caldwell, M.: Effects of growth under elevated UVB on photosynthesis and isoprene emission in Quercus gambelii and Mucuna pruriens, Glob. Change Biol., 2, 149-154, 1996.

Hays, G. C., Richardson, A. J., and Robinson, C.: Climate change and plankton, Trends Ecol. Evol., 20, 337-344, doi:10.1016/j.tree.2005.03.004, 2005.

Hoffman, E. J. and Duce, R. A.: Factors influencing the organic carbon content of marine aerosols: A laboratory study, J. Geophys. Res., 81, 3667-3670, doi:10.1029/JC081i021p03667, 1976.

Holm-Hansen, D. and Riemann, B.: Chlorophyll $a$ determination: improvements in methods, Oikos, 30, 438-447, 1978.

Hoose, C., Kristjánsson, J. E., Iversen, T., Kirkevåg, A., Seland, Ø., and Gettelman, A.: Constraining cloud droplet number concentration in GCMs suppresses the aerosol indirect effect, Geophys. Res. Lett., 36, L12807, doi:10.1029/2009GL038568, 2009.

Huner, P. A., Oquist, G., and Sarhan, F.: Energy balance and acclimation to light and cold, Trends Plant Sci., 3, 224-230, 1998.

Juneja, A., Ceballos, R. M., and Murthy, G. S.: Effects of Environmental Factors and Nutrient Availability on the Biochemical Composition of Algae for Biofuels Production: A Review, Energies, 6, 4607-4638, doi:10.3390/en6094607, 2013.

Kameyama, S., Tanimoto, H., Inomata, S., Suzuki, K., Komatsu, D. D., Hirota, A., Konno, U., and Tsunogai, U.: Application of PTRMS to incubation experiments of the marine diatom Thalassiosira pseudonana, Geochem. J., 45, 355-363, 2011.

Koppmann, R. and Wildt, J.: Oxygenated Volatile Organic Compounds, In: Volatile Organic Compounds in the Atmosphere, edited by: Koppmann, R., 129-172, Blackwell Publishing Ltd., Oxford, 2007.

Langdon, C.: On the causes of interspecific differences in the growth-irradiance relationship for phytoplankton, Part II, A general review, J. Plankton Res., 10, 1291-312, 1988.
Liakakou, E., Vrekoussis, M., Bonsang, B., Donousis, C., Kanakidou, M., and Mihalopoulos, N.: Isoprene above the Eastern Mediterranean: Seasonal variation and contribution to the oxidation capacity of the atmosphere, Atmos. Environ., 4, 1002-1010, doi:10.1016/j.atmosenv.2006.09.034, 2007.

Lichtenthaler, H. K.: The 1-deoxy-D-xylulose-5-phosphate pathway of isoprenoid biosynthesis in plants, Annu. Rev. Plant Physiol. Plant Mol. Biol., 50, 47-65, 1999.

Lichtenthaler, H. K.: Biosynthesis and Accumulation of Isoprenoid Carotenoids and Chlorophylls and Emission of Isoprene by Leaf Chloroplasts, Bull. Georg. Natl. Acad. Sci., 3, 81-94, 2009.

Luo, G. and Yu, F.: A numerical evaluation of global oceanic emissions of a-pinene and isoprene, Atmos. Chem. Phys., 10, 20072015, doi:10.5194/acp-10-2007-2010, 2010.

MacIntyre, H. L, Kana, T. M., Anning, J., and Geider, R.: Photoacclimation of photosynthesis irradiance response curves and photosynthetic pigments in microalgae and cyanobacteria, J. Phycol., 38, 17-38, doi:10.1046/j.1529-8817.2002.00094.x, 2002.

McKay, W. A., Turner, M. F., Jones, B. M. R., and Halliwell, C. M.: Emissions of hydrocarbons from marine phytoplankton-some results from controlled laboratory experiments, Atmos. Environ., 30, 2583-2593, 1996.

Meskhidze, N. and Nenes, A.: Phytoplankton and cloudiness in the Southern Ocean, Science, 314, 1419-1423, doi:10.1126/science.1131779, 2006.

Meskhidze, N., Xu, J., Gantt, B., Zhang, Y., Nenes, A., Ghan, S. J., Liu, X., Easter, R., and Zaveri, R.: Global distribution and climate forcing of marine organic aerosol: 1. Model improvements and evaluation, Atmos. Chem. Phys., 11, 11689-11705, doi:10.5194/acp-11-11689-2011, 2011.

Meskhidze, N., Petters, M. D., Tsigaridis, K., Bates, T., O’Dowd, C., Reid, J., Lewis, E. R., Gantt, B., Anguelova, M. D., Bhave, P. V., Bird, J., Callaghan, A. H., Ceburnis, D., Chang, R., Clarke, A., de Leeuw, G., Deane, G., DeMott, P. J., Elliot, S., Facchini, M. C., Fairall, C. W., Hawkins, L., Hu, Y., Hudson, J. G., Johnson, M. S., Kaku, K. C., Keene, W. C., Kieber, D. J., Long, M. S., Martensson, M., Modini, R. L., Osburn, C. L., Prather, K. A., Pszenny, A., Rinaldi, M., Russell, L. M., Salter, M., Sayer, A. M., Smirnov, A., Suda, S. R., Toth, T. D., Worsnop, D. R., Wozniak, A., and Zorn, S. R.: Production mechanisms, number concentration, size distribution, chemical composition, and optical properties of sea spray aerosols, Atmos. Sci. Lett., 14, 207-213, doi:10.1002/asl2.441, 2013.

Milne, P. J., Riemer, D. D., Zika, R. G., and Brand, L. E.: Measurement of vertical distribution of isoprene in surface seawater, it chemical fate, and its emission from several phytoplankton monocultures, Mar. Chem., 48, 237-244, 1995.

Moore, R. M., Oram, D. E., Penkett, S. A.: Production of isoprene by marine-phytoplankton cultures, Geophys. Res. Lett., 21, 2507-2510, doi:10.1029/94GL02363, 1994.

O'Dowd, C. D. and de Leeuw, G.: Marine aerosol production: a review of the current knowledge, Phil. Trans. R. Soc. A, 365, 1753-1774, 2007.

O’Dowd, C. D., Facchini, M. C., Cavalli, F., Ceburnis, D., Mircea, M., Decesari, S., Fuzzi, S., Yoon, Y. J., and Putaud, J. P.: Biogenically driven organic contribution to marine aerosol, Nature, 431, 676-680, doi:10.1038/nature02959, 2004. 
Palmer, P. I. and Shaw, S. L.: Quantifying global marine isoprene fluxes using MODIS chlorophyll observations, Geophys. Res. Lett., 32, L09805, doi:10.1029/2005GL022592, 2005.

Platnick, S. and Twomey, S.: Determining the susceptibility of cloud albedo to changes in droplet concentration with the Advanced Very High Resolution Radiometer, J. Appl. Meteorol., 33, 334-347, 1994

Randall, D. A., Coakley, Jr., J. A., Fairall, C. W., Kropfli, R. A., and Lenschow, D. H.: Outlook for research on subtropical marine stratocumulus clouds, B. Am. Meteorol. Soc., 65, 1290-1301, 1984.

Rinnan, R., Steinke, M., McGenity, T., and Loreto, F.: Plant volatiles in extreme terrestrial and marine environments, Plant Cell Environ., 37, 1776-1789, doi:10.1111/pce.12320, 2014.

Roelofs, G. J.: A GCM study of organic matter in marine aerosol and its potential contribution to cloud drop activation, Atmos. Chem. Phys., 8, 709-719, doi:10.5194/acp-8-709-2008, 2008.

Schofield, O., Grzymski, J., Moline, M. M. A., and Jovine, R. V. M.: Impact of temperature acclimation on photosynthesis in the toxic red-tide dinoflagellate Alexandrium fundyense (Ca28), J. Plankton Res., 20, 1241-1258, 1998.

Sharkey, T. D. and Yeh, S.: Isoprene emission from plants, Annu. Rev. Plant Phys., 52, 407-436, 2001.

Sharkey, T. D., Wiberley, A. E, and Donohue, A. R.: Isoprene emission from plants: why and how, Ann. Bot., 101, 5-18, doi:10.1093/aob/mcm240, 2008.

Shaw, G. E.: Bio-controlled thermostasis involving the sulfur cycle, Climatic Change, 5, 297-303, 1983
Shaw, S. L., Chisholm, S. W., and Prinn, R.: Isoprene production by Prochlorococcus, a marine cyanobacterium, and other phytoplankton, Mar. Chem, 80, 227-245. 2003.

Shaw, S. L., Gantt, B., and Meskhidze, N.: Production and Emissions of Marine Isoprene and Monoterpenes: A Review, Adv. Meteorol., 2010, 408696, doi:10.1155/2010/408696, 2010.

Staehr, P. A. and Birkeland, M. J.: Temperature acclimation of growth, photosynthesis and respiration in two mesophilic phytoplankton species, Phycologia, 45, 648-656, doi:10.2216/06-04.1, 2006.

Stevens, B., Vali, G., Comstock, K., Wood, R., Van Zanten, M. C., Austin, P. H., Bretherton, C. S., and Lenschow, D. H.: Pockets of Open Cells (POCs) and Drizzle in Marine Stratocumulus, B. Am. Meteorol. Soc., 86, 51-57, doi:10.1175/BAMS-86-1-51, 2005.

WDNR: Analytical Detection Limit Guidance and Laboratory Guide for Determining Method Detection Limits, PUBL-TS056-96, Wisconsin Department of Natural Resources, 24 pp., 1996.

Wolfe, G. V., Strom, S. L., Holmes, J. L, Radzio, T., and Olson, M. B.: Dimethylsulfoniopropionate cleavage by marine phytoplankton in response to mechanical, chemical, or dark stress, J. Phycol, 38, 948-960, doi:10.1046/j.1529-8817.2002.t01-1-01100.x, 2002.

Yassaa, N., Peeken, I., Zollner, E., Bluhm, K., Arnold, S., Spracklen, D., and Williams, J.: Evidence for marine production of monoterpenes, Environ. Chem. Lett., 5, 391-401, doi:10.1071/EN08047, 2008. 